\title{
Determination of Secondary School Students' Levels of Sensitivity towards Cyberbullying and Cyberbullying Behaviour
}

\author{
Şemseddin Gündüz* \\ CEIT Department, Necmettin Erbakan University, Konya, Turkey \\ Orcid: 0000-0003-1075-0043
}

Fatma Akgün

CEIT Department, Trakya University, Edirne, Turkey

Orcid: 0000-0002-9728-7516

\section{Hasan Özgür}

CEIT Department, Trakya University, Edirne, Turkey

Orcid: 0000-0002-8035-0320,

\begin{tabular}{ll}
\hline \hline Article history & The development of technology and especially the changes and \\
Received: & innovations experienced in the development of mobile \\
17.04 .2020 & technologies have increased the use of such technological devices \\
Received in revised form: & in the society. Mobile technologies and smart phones among them \\
13.06 .2020 & have positive effects both in social life and academic life, alongside \\
Accepted: & situations that cause some negative consequences as a result of \\
10.07 .2020 & intensive use of such technologies. Cyberbullying behaviour, \\
Key words: & which aims to harm others' lives by using technological devices, \\
\hline $\begin{array}{l}\text { Cyberbullying; } \\
\text { censitivity towards }\end{array}$ & comes to the forefront among these problems. Therefore, this study \\
Secondary school; & aims to investigate engagement in cyberbullying behaviour and the \\
Student & sensitivity towards cyberbullying, which is a common behaviour \\
& especially among secondary school students. The study was \\
& carried out with 747 secondary school students studying in the first \\
& and second year in the fall term of the 2019-2020 academic year. \\
"Cyberbullying Scale" and "Sensitivity towards Cyberbullying \\
Scale" were used for data collection. Descriptive statistics, Mann \\
Whitney U and Kruskal Wallis H and Spearman rho tests were \\
used to evaluate the data that were found not to show normal \\
distribution. As a result of the study, it was determined that the \\
students' levels of engagement in cyberbullying behaviour were \\
"low", whereas their sensitivity levels towards cyberbullying were \\
"high". In the study, it was revealed that there is a difference \\
between students' engaging in cyberbullying behaviour and their \\
sensitivity towards cyberbullying in terms of gender and grade \\
variables. While in the study it was revealed that difference
\end{tabular}

* Correspondency: semsedding@gmail.com 
between their cyberbullying behaviour and phone ownership variable were found to be significant, the difference between their cyberbullying sensitivity levels and mother education level, father education level, computer ownership, tablet ownership variables, were also found to be significant. However, it was determined that there was a negative and moderate relationship between their cyberbullying behaviour and their sensitivity towards cyberbullying.

\section{Introduction}

The development of technology and especially the changes and innovations experienced in the development of mobile technologies have increased the use of such technological devices in the society. Analysing the age group, it is seen that especially young people spend a lot of time with such mobile technologies. Hardware and software innovations carried out on mobile technologies attract a lot of attention of young people and consequently increase the number of users and usage time of mobile technologies. Blogs, social networks and instant messages, which are among the dominant tools and methods of personal interaction, have replaced faceto-face interaction and are situated at the centre of life (Hinduja \& Patchin, 2008). In addition to the fact that mobile technologies containing such applications, including smart phones, among these have positive effects in both social life and academic life, there are situations that cause some negative situations as a result of intensive use of such technologies. For example, Horzum and Ayas (2014) stated that people who follow the development of information technologies with great care can often use these technologies to harm others, apart from their main purposes. Regarding the unconscious use of such technologies in the school environment, $\mathrm{Li}$ (2006) emphasized that although computers used in the classroom environment have positive effects on the course activities; bringing electronic communication devices to classes may cause serious problems in schools. As can be seen, cyberbullying is one of the behaviours that should be taken into consideration amongst others that lead to negative behaviour caused by using technological devices in daily and academic life.

\section{Cyberbullying}

Cyberbullying is a phenomenon that aims to harm others' lives by using information and communication technologies and becomes a serious problem in the society and is a holistic term that includes similar concepts such as online bullying, electronic bullying and internet harassment (Kowalski \& Limber, 2007). Considering the definition of cyberbullying in the literature, Patchin and Hinduja (2006) refer to it as a "willful and repeated harmful behaviour given through an electronic text", while Tokunaga (2010) stated it as "an act of repeatedly transmitting hostile and offensive messages aimed at causing harm and/or discomfort to others by using electronic and/or digital media tools by an individual or group of individuals" (Patchin \& Hinduja, 2006, p. 152; Tokunaga, 2010, p. 278). While Arıcak (2011) emphasized the definition of cyberbullying as "all the behaviour that are carried out for private or legal personality of any individual or group using technical information and communication technologies (ICT), which are carried out in a technical or relational manner", Belsey (2015) emphasized that "cyberbullying is a form of immoral and antisocial behaviour that affects parents, teachers, education and well-being of our children and young people, and rapidly emerges and brings frightening difficulties". Cyberbullying often involves sending harassing and threatening emails and instant messages, making humiliating comments about someone on a website, physically threatening and frightening someone online (Patchin \& Hinduja, 2010) as 
well as malicious behaviour like insulting, preparing embarrassing web pages about individuals and excluding an individual in a virtual environment via ICT (Keser \& Kavuk, 2015). On the other hand, besides cyberbullying behaviour is similar to traditional bullying, it is more difficult to escape and hide from cyberbullying attacks compared to traditional bullying (Rao et al., 2017). While traditional bullying tends to occur in situations where the offender and the victim are in close environments, cyberbullying tends to occur remotely, mostly using computers and the internet. Examples of technologies used for cyberbullying include computers, mobile phones, tablets, cameras, or other electronic devices (Varela et al., 2018). On the other hand, the common aspect in both types of bullying is that they both have permanent negative emotional and behavioural consequences on the victim (Patchin \& Hinduja, 2010). Cyberbullying creates a more dangerous situation than traditional bullying in terms of hiding the identity, communicating with the victim at any time and having the potential to reach many people in a short time. In recent years, especially with the widespread of digital technologies, the traditional form of aggression experienced face to face has been replaced by cyber aggression, in other words, cyberbullying (Jimenez, 2019). Cyberbullying behaviour may be for technical disturbance, which aims to create hardware and software problems on devices, or personal discomfort, which aims to make fun of the individual's physical and emotional appearance. While technical disturbance is considered as a form of an electronic bullying (ebullying) through making the hardware of systems inoperable, getting passwords, hacking websites and sending spam mails, personal disturbance is constantly disturbing, mocking, naming, spreading gossip, and e-communication bullying, which includes actions to spread personal images and information using technological devices (Arıcak, 2011).

\section{Literature Review}

Cyberbullying is a serious public health problem with devastating effects for the victim, families, educators, managers, schools and the wider community (Alotaibi, 2019; Kavuk Kalender, Keser, \& Tugun, 2019; Ronis \& Slaunwhite, 2019; Sampasa-Kanyinga, Lalende, \& Colman, 2020; Tanrikulu, 2017), and it is also generally accepted as a global problem that arises with increased social media use (Kasahara, Houlihan, \& Estrada, 2019). On the other hand, it is stated in many studies that this behaviour has reached an alarming level among the society (Chan \& Wong, 2019; Dinakar, Reichart, \& Lieberman, 2011; Wang, Wang, \& Lei, 2019). However, children and young people can participate in cyberbullying behaviour in various roles. Regarding this issue Pekşen Süslü and Oktay (2018) emphasized that cyberbullying and cyber victimization are universal problems witnessed among adolescents and children. Children and adolescents can be involved in this kind of behaviour to their peers regardless of gender. Likewise, both boys and girls can get engaged in this behaviour regardless of gender differences. For example, whereas it is revealed that boys engage in cyberbullying behaviour more than girls (Arıcak \& Özbay, 2016; Chan \& Wong, 2019; Huang \& Chou, 2010; Kavuk \& Keser, 2016), according to some studies, girls engage in cyberbullying behaviour more than boys (Eroğlu et al., 2015; Kowalski \& Limber, 2007; Wolak et al., 2007).

People who carry out cyberbullying behaviour in the society are defined as "cyber bully", whilst those who are exposed to the behaviour are defined as "cyber victims" (Kavuk Kalender et al., 2019). Cases such as frustration, sadness, anger (Kestel \& Akbiyık, 2016; Rao et al., 2017; Yaman \& Peker, 2012), fear and tension (Alotaibi, 2019), insecurity, anxiety and high depression (Ronis \& Slaunwhite, 2019), psychological and social effects (Yiğit, Keskin, \& Yurdugül, 2018), emotional, behavioural and academic problems (Aizenkot \& KashyRosenbaum, 2019), low self-esteem, emotional and psychological problems, academic difficulties, clinical depression (Hinduja \& Patchin, 2010), having negative relationships with family and friends (Kestel \& Akbiyık, 2016), not being able to communicate socially (Ciftci, 
2018), feeling of revenge (Yaman \& Peker, 2012) and feeling humiliated, isolated and anxious (Simangunsong, 2020) are among the effects of cyberbullying victimization. Similarly, it was emphasized in the studies conducted to examine cyberbullying behaviour that cyberbullying can have a negative impact on academic success (Alotaibi, 2019; Tanrikulu, 2018). That said, Eroğlu and Güler (2015) stated that cyberbullying and cyber victimization have very serious negative effects in terms of individuals' social environment, academic and emotional lives. Cyberbullying is considered as an issue that should be given importance in schools and communities due to the emotional, psychological and even physical harm that victims may experience (Batmaz \& Ayas, 2013; Patchin \& Hinduja, 2010). In this regard, Chibbaro (2007) commented that cyberbullying behaviour has become an issue of concern for educators in recent years, in fact, Patchin and Hinduja (2010) also commented that bullying and peer harassment issues have been a concern for educators for a long time, and a significant part of adolescents are affected by it. This situation impacts not only educators but also family members rather negatively. For this reason, family members should also be conscious of their children not to be involved in and / or be exposed to such behaviours (Kavuk Kalender et al., 2019; Ronis \& Slaunwhite, 2019; Sampasa-Kanyinga et al., 2020; Tanrıkulu, 2017). As a matter of fact, there are also studies in the literature that state that education levels of mothers, fathers and family members have an important effect in order not to get engaged in such behaviours (Eroğlu et al., 2015; Laftman, Modin, \& Östberg, 2013). As can be seen, the widespread of information and communication technologies (ICT) has caused the spread of adolescent peer aggression and this has become a situation that should be taken seriously both at school and at home (Altundag \& Ayas, 2020; Hinduja \& Patchin, 2010). Erdur-Baker and Kavşut (2007) pronounced that uncontrolled and unprotected use of the opportunities provided by ICT causes some adversities that are called peer bullying. Especially the unlimited access of young people to ICT means that bullying can occur at anytime and anywhere (Cross et al., 2016). Regarding this issue, while Smith et al. (2008) emphasized that especially via mobile phones and the Internet, the use of such technologies can also increase the risk of cyberbullying, Simangunsong (2020) accentuated that various functions of smart phones can create new problems e.g. cyberbullying. In a similar vein, there are studies that indicate that cyberbullying has become more evident and increased as a result of the use of internet-enabled mobile phones and computers in the literature (Hinduja \& Patchin, 2008; Smith et al., 2006). In addition, various studies have been carried out in the literature on the emergence of cyberbullying behaviour at the grade and school levels. Regarding this issue Aizenkot and Kashyrosenbaum (2019) emphasized that cyberbullying behaviour increased in primary school compared to secondary and high school in his research conducted with primary, secondary and high school students. When we look at research on cyberbullying, it is observed that especially students of secondary and high school perform such negative behaviour at a high rate (Kavuk Kalender et al., 2019; Rao et al., 2017) and cyber victimization is an important problem among secondary and high school students (Duman \& Bridge, 2019). At the same time, many studies investigating cyberbullying behaviour of secondary school students (Aizenkot \& Kashy-Rosenbaum, 2019; Antoniadou \& Kokkinos, 2018; Balaban Sali, Ergün Başak, \& Baştürk Akça, 2015; Başturk Akça, Sayımer, \& Ergül, 2015; Chan \& Wong, 2019; Jimenez, 2019 ; Kavuk Kalender et al., 2019; Keser \& Kavuk, 2015; Kestel \& Akbıy1k, 2016; Peker, 2015; Rao et al., 2017; Toraman \& Usta, 2018; Wang et al., 2019; Yiğit et al., 2018;), high school students (Aizenkot \& Kashy Rosenbaum, 2019; Bingöl \& Tanrıkulu, 2014; Ciftci, 2018; Dilmac \& Ozkan, 2019; Eristi \& Akbulut, 2017; Kavuk Kalender et al., 2019; Keser \& Kavuk, 2015; Özdemir \& Akar, 2011; Pekşen Süslü \& Oktay, 2018; Rao et al., 2017; Şahin et al., 2010) and college and university students (Bauman \& Baldasare, 2015; Ciftci, 2018; Eristi \& Akbulut, 2017; Gezgin \& Çuhadar, 2012; MacDonald \& Roberts Pittman, 2010; Özgür, 2015) can be found in the literature. For example, Akbaba and Eroğlu (2013) emphasized that cyberbullying among primary school students started to 
become a major problem in the studies conducted in Turkey. It is also important to this behaviour being realized especially for the secondary school students who are in the transition period to adolescence constituting an important risk group (Yiğit et al., 2018). Cross et al. (2016) stated that cyberbullying behaviour increases in the transition period of students from primary school to secondary school, and especially the first 2 years of secondary school would be the appropriate time to intervene in this behaviour (Cross et al., 2016). Therefore, school policies and culture play a vital role in the prevention of cyberbullying and these are among the main factors to be considered in terms of alleviating this behaviour (Varela et al., 2018). In this regard Kurniasih, Kurwarno, Yanto and Sugiana (2020), stated that the school, parents, students, environmental conditions and legal regulations are among the important factors for minimizing cyberbullying behaviour among children. As a matter of fact, in many studies, it was underlined that the social relationships of adolescents, particularly with their parents, have an important effect on their tendency to continue bullying behaviour (Chan \& Wong, 2019; Sampasa-Kanyinga et al., 2020; Tanrıkulu, 2019; Yiğit et al., 2018). Of these studies, SampasaKanyinga et al. (2020) stated that a positive parent-child relationship has a buffering effect on the adolescent risk taking and negative outcomes. In many literature studies, it is pinpointed that there is a need for the support of administrators, faculty members, teachers, parents and school counsellors in developing measures for preventing and interfering cyberbullying (Beale \& Hall, 2020; Chibbaro, 2007; Li, 2006). In this sense, Beale and Hall (2020) underpinned the need for educators to understand the nature of this situation and to be aware of actions to prevent cyberbullying in schools to combat cyberbullying.

On the other hand, ensuring individuals' sensitivity in this context in order not to be exposed to cyberbullying behaviour, which concerns a large part of the society and especially causes serious psychological problems among children and young people, can be considered as a remarkable factor as regards the solution to the problem. While sensitivity is defined as staying away and avoiding any threatening stimuli, sensitivity towards cyberbullying is, "avoiding behaviour that may lead to exposure to bullying behaviour during the use of virtual tools such as the internet, mobile phones, being aware of the existence of such threats, taking precautions and keeping attention to these behaviour high" (Tanrikulu, Kinay \& Arıcak, 2013, p. 40). Therefore, individuals with high sensitivity are more careful towards their environment, they can refrain from any threat, teasing, hurting or malicious behaviour that adversely affect them, they can develop measures on their own and they may be more aware of this issue. In particular, individuals who spend most of the day in the virtual world, and specifically children and young people, are expected to have improved cyberbullying sensitivity towards any behaviour that may take place in the virtual world. As can be seen in the studies of the literature, this situation appears to be a very serious one among secondary school students, where cyberbullying behaviour occurs frequently. On the other hand, it is a very important issue for students to be sensitive about cyberbullying behaviour, which may occur frequently both in school environment and in social life, not to be exposed to such behaviours or to raise awareness of their peers in this regard. However, although sensitivity is also an issue to be taken into consideration, it has been observed that studies on both cyberbullying behaviour and determining the sensitivity of this behaviour are not sufficient in number in the literature. Therefore, since it is known that cyberbullying affects both cyber bullies and cyber victims negatively, it is also very important to carry out studies involving cyberbullying behaviour, sensitivity towards cyberbullying and solutions. In this context, the purpose of the study is to determine secondary school students' levels of engagement in cyberbullying behaviour and their sensitivity towards cyberbullying. Within the scope of this general purpose, answers to the following questions were sought: 
(1) What is the level of students' engagement in cyberbullying and their sensitivity towards cyberbullying?

(2) Does the level of students' engagement in cyberbullying and their sensitivity towards cyberbullying vary according to gender, education level, education level of parents, and owned information technology tools?

(3) Is there a significant relationship between students' levels of engagement in cyberbullying and their sensitivity towards cyberbullying?

\section{Method}

This research is a descriptive research and was carried out using the relational survey model. According to Karasar (2005), in the relational survey model; it is aimed to determine the change between two or more variables and/or the degree of this change. The relationships found through scanning are interpreted in the context of providing a prediction of the other variable if the situation in a variable is known rather than a cause and effect relationship. In this study carried out in this direction, the relationship between students' levels of Sensitivity towards Cyberbullying and the engagement in Cyberbullying behaviour were tried to be resolved by using the correlation type relational survey model. The comparison type relational survey model was used to determine whether there is a difference between gender, education level, education level of mother and father, owned information technology devices and level of Sensitivity towards Cyberbullying and engagement in Cyberbullying behaviour.

\section{Study Group}

The study group of the research consists of 747 secondary school students, 302 of who are females $(40.4 \%)$ and 445 of who are males (59.6\%), these are studying in the first and second year secondary school (middle school) students in Turkey during the 2019-2020 academic year. Demographic information about the students participating in the research is presented in Table 1.

Table 1. Demographic characteristics of students

\begin{tabular}{|c|c|c|c|c|c|}
\hline Gender & $\mathbf{N}$ & $(\%)$ & Father Education Level & $\mathbf{N}$ & $(\%)$ \\
\hline Female & 302 & 40.4 & Illiterate & 19 & 2.5 \\
\hline \multirow[t]{2}{*}{ Male } & 445 & 59.6 & Primary School & 96 & 12.9 \\
\hline & & & Secondary School & 201 & 26.9 \\
\hline Grade Level & $\mathbf{N}$ & $(\%)$ & High School & 221 & 29.6 \\
\hline $1^{\text {st }}$ year & 294 & 39.4 & Undergraduate and above & 210 & 28.1 \\
\hline \multirow[t]{2}{*}{$2^{\text {nd }}$ year } & 453 & 60.6 & & & \\
\hline & & & $\begin{array}{l}\text { Information Technology } \\
\text { Devices Owned }\end{array}$ & $\mathbf{N}$ & $(\%)$ \\
\hline Mother Education Level & $\mathbf{N}$ & $(\%)$ & Personal Computer & 366 & 49.0 \\
\hline Illiterate & 29 & 3.9 & Tablet & 407 & 54.5 \\
\hline Primary School & 173 & 23.2 & Mobile Phone & 418 & 56.0 \\
\hline Secondary School & 233 & 31.2 & No device owned & 72 & 9.6 \\
\hline High School & 195 & 26.1 & & & \\
\hline Undergraduate and above & 117 & 15.7 & & & \\
\hline
\end{tabular}

\section{Data Collection Tools}

For collecting data in the research, the "Cyberbullying Scale" developed by Aricak, Kınay and Tanrıkulu (2012), and the "Cyberbullying Sensitivity Scale" developed by 
Tanrikulu, Kınay and Arıcak (2013) were used. On the other hand, the "Personal Information Form" developed by the researchers was used to determine the demographic characteristics of the participants and their habits related to social networks.

Cyberbullying Scale: The Cyberbullying Scale developed by Arıcak, Kınay and Tanrıkulu (2012) was used to get students' opinions about cyberbullying. The scale consists of one factor and this single factor explains $50.58 \%$ of the total variance. Factor loads of the items vary between .49 and .80 . Cronbach's Alpha coefficient calculated for the whole scale is .95; testretest reliability coefficient was found as .70. The scale consists of 24 items and is answered on a four point (Never, Sometimes, Often, Always) scale. Scoring of the scale is; Never = 1, Sometimes $=2$, Often $=3$ and Always $=4$. The lowest score that can be obtained from the scale is 24 , and the highest score is 96 . The high score obtained from the scale indicates that the individual is a cyberbully (Arıcak, Kınay \& Tanrıkulu, 2012).

Cyberbullying Sensitivity Scale: The data required to determine students' sensitivity towards cyberbullying was collected with the Cyberbullying Sensitivity Scale developed by Tanrikulu, Kinay, and Aricak (2011). The scale consists of one factor and this single factor explains $27.70 \%$ of the total variance. Factor loads of the items vary between .32 and .73. The Cronbach's Alpha coefficient calculated for the entire scale is .79; test-retest reliability coefficient was found as .66. The scale consists of 14 items and is answered on a three point (No, Sometimes, Yes) answer scale. Scoring of the scale is No $=1$, Sometimes $=2$ and Yes $=$ 3 . The lowest score that can be obtained from the scale is 14 , and the highest score is 42 . The high score obtained from the scale indicates the high sensitivity towards cyberbullying (Tanrıkulu, Kınay, \& Arıcak, 2011).

Personal Information Form: In the research, the personal information form was used in order to obtain demographic information belonging to the students constituting the study group.

\section{Data Collection and Analysis}

The data were collected by the researchers in the fall semester of the 2019-2020 academic year. Students were firstly informed about the subject of research and data collection tools, and then students were asked to answer the scales by reminding that participation in the research was voluntary. The scales were answered in about 20 minutes. Central distribution, skewness and kurtosis values were examined on the factors in both scales. The result of Kolmogorov-Smirnov Test performed on the scales was found as $\mathrm{p}<0.05$ and it was concluded that the data did not show normal distribution. Descriptive statistics, Mann Whitney U and Kruskal Wallis $\mathrm{H}$ and Spearman rho tests were used to evaluate the data that were found not to show normal distribution. The significance level was accepted as .05 in comparisons.

\section{Results}

The findings, obtained by the cyberbullying and cyberbullying sensitivity scales, show that the mean score of the students' engagement in cyberbullying behaviour $(\bar{X}=28.83)$ is low and the mean score of their cyberbullying sensitivity $(\bar{X}=34.05)$ is high, and it can be seen in Table 2. 
Table 2. Descriptive statistics of students' engagement in cyberbullying behaviour and their sensitivity towards cyberbullying

\begin{tabular}{llll}
\hline Variable & $\boldsymbol{n}$ & $\overline{\boldsymbol{X}}$ & $\boldsymbol{S D}$ \\
\hline Engaging in Cyberbullying Behaviour & 747 & 28.83 & 10.82 \\
Sensitivity towards Cyberbullying & 747 & 34.05 & 6.13 \\
\hline
\end{tabular}

Mann Whitney U test was used to test the significance of the difference between students' engagement in cyberbullying behaviour and their sensitivity towards cyberbullying in terms of the gender variable. According to the findings presented in Table 3, it is seen that there is a significant difference $\left(U_{l}=57820.50, p<.05 ; U_{2}=57667.00, p<.05\right)$ in the context of the gender variable and the scores of cyberbullying behaviour and cyberbullying sensitivity. That is, the mean scores of cyberbullying behaviour of male students were significantly higher than that of female students. On the other hand, it has been found out that the mean scores of sensitivity towards cyberbullying of female students were higher than that of male students.

Table 3. U-test result regarding the students' levels of engagement in cyberbullying behaviour and sensitivity towards cyberbullying in terms of gender variable

\begin{tabular}{|c|c|c|c|c|c|c|}
\hline Variable & Gender & $n$ & $\begin{array}{l}\text { Mean } \\
\text { Rank }\end{array}$ & $\begin{array}{l}\text { Sum of } \\
\text { Ranks }\end{array}$ & $\boldsymbol{U}$ & $p$ \\
\hline Engaging in Cyberbullying & Female & 302 & 342.96 & 103573.50 & & \\
\hline Behaviour & Male & 445 & 395.07 & 175804.50 & 7820.50 & .000 \\
\hline Sensitivity & Female & 302 & 405.55 & 122476.00 & & \\
\hline Cyberbullying & Male & 445 & 352.59 & 156902.00 & 57667.00 & .001 \\
\hline
\end{tabular}

The relationship between the students' grade level of education and the level of sensitivity towards cyberbullying and engaging in cyberbullying behaviour was investigated with the Mann Whitney U Test. The mean score of cyberbullying behaviour engagement of students studying in the first year was significantly higher than those studying in the second year secondary school students $\left(U_{l}=57873.50, p<.05\right)$. On the other hand, the mean score of sensitivity towards cyberbullying among students studying in the second year was significantly higher than the mean score of the first year secondary school students $\left(U_{2}=50371.00, p<.05\right)$.

Table 4. U-test result regarding the students' engagement in cyberbullying behaviour, cyber victimization and sensitivity towards cyberbullying in terms of grade level variable

\begin{tabular}{|c|c|c|c|c|c|c|}
\hline Variable & Grade & $n$ & $\begin{array}{l}\text { Mean } \\
\text { Rank }\end{array}$ & $\begin{array}{l}\text { Sum } \\
\text { Ranks }\end{array}$ & $\boldsymbol{U}$ & $p$ \\
\hline Engaging in Cyberbullying & $1^{\text {st }}$ year & 294 & 403.65 & 118673.50 & \multirow{2}{*}{57873.50} & \multirow{2}{*}{.001} \\
\hline Behaviour & $2^{\text {nd }}$ year & 453 & 354.76 & 160704.50 & & \\
\hline Sensitivity & $1^{\text {st }}$ year & 294 & 318.83 & 93736.00 & & \\
\hline Cyberbullying & $2^{\text {nd }}$ year & 453 & 409.81 & 185642.00 & 50371.00 & .000 \\
\hline
\end{tabular}

The education levels of the mothers of the students and their cyberbullying engagement and sensitivity levels towards cyberbullying were investigated with the Kruskal Wallis $\mathrm{H}$ Test. While the analysis results revealed that there was no difference between the mother education level variable and the mean scores regarding the engagement in cyberbullying behaviour $\left(\chi_{1}^{2}(\mathrm{df}=4, \mathrm{n}=747)=1.28, \mathrm{p}>.05\right)$, there was a significant difference between the mean scores of sensitivity towards cyberbullying $\left(\chi_{2}^{2}(\underline{\mathrm{df}}=4, \mathrm{n}=747)=13.13, \mathrm{p}<.05\right)$. In order to determine the source of the difference observed between the groups, Mann Whitney U-tests were applied over the binary combinations of the groups. As a result of the analysis, it was determined that the 
sensitivity towards cyberbullying is highest among the students whose mother education level is undergraduate and above, and the sensitivity towards cyberbullying of the students whose mother is illiterate is the lowest. The findings are presented in Table 5.

Table 5. Kruskal Wallis $H$ test result regarding the level of cyberbullying and cyberbullying sensitivity in terms of the mother education level variable

\begin{tabular}{llllllll}
\hline Variable & Education Level & $\boldsymbol{n}$ & $\begin{array}{l}\text { Mean } \\
\text { Rank }\end{array}$ & $\boldsymbol{d f}$ & $\chi^{2}$ & $\boldsymbol{p}$ & $\begin{array}{l}\text { Sig. } \\
\text { Dif. }\end{array}$ \\
\hline Engaging in & Illiterate (A) & 29 & 404.59 & & & & \\
Cyberbullying & Primary School (B) & 173 & 376.20 & & & & \\
Behaviour & Secondary School (C) & 233 & 378.20 & 4 & 1.28 & .865 & \\
& High School (D) & 195 & 366.09 & & & & \\
& Undergraduate and above & 117 & 367.99 & & & & \\
& (E) & & & & & & \\
Sensitivity & Illiterate (A) & 29 & 285.90 & & & & \\
towards & Primary School (B) & 173 & 363.35 & & & & \\
Cyberbullying & Secondary School (C) & 233 & 355.67 & & & \\
& High School (D) & 195 & 392.48 & 4 & 13.13 & .011 & E-A \\
& Undergraduate and above & 117 & 417.29 & & & & \\
& (E) & & & & & & \\
\hline
\end{tabular}

The education level of the fathers of the students and their cyberbullying engagement and sensitivity levels towards cyberbullying were investigated with the Kruskal Wallis $\mathrm{H}$ Test. While the analysis results revealed that there was no difference between the father education level variable and the averages regarding the engagement in cyberbullying behaviour $\left(\chi_{1}^{2}(\mathrm{df}=4\right.$, $\mathrm{n}=747)=8.08, \mathrm{p}>.05)$, there was a significant difference between the mean scores of sensitivity towards cyberbullying $\left(\chi_{2}^{2}(\mathrm{df}=4, \mathrm{n}=747)=15.51, \mathrm{p}<.05\right)$. In order to determine the source of the difference observed between the groups, Mann Whitney U-tests were applied over the binary combinations of the groups. As a result of the analysis, it was determined that the sensitivity towards cyberbullying is highest among the students with a father's education level of undergraduate and above, and the sensitivity towards cyberbullying of the students whose father is a secondary school graduate is at the lowest level. The findings are presented in Table 6.

Table 6. Kruskal Wallis $\mathrm{H}$ test result regarding the level of engagement in cyberbullying and cyberbullying sensitivity in terms of the father education level variable

\begin{tabular}{llllllll}
\hline Variable & Education Level & $\boldsymbol{n}$ & $\begin{array}{l}\text { Rank } \\
\text { Mean }\end{array}$ & $\boldsymbol{d f}$ & $\chi^{\mathbf{2}}$ & $\boldsymbol{P}$ & $\begin{array}{l}\text { Sig. } \\
\text { Dif. }\end{array}$ \\
\hline Engaging in & Illiterate (A) & 19 & 386.32 & & & & \\
Cyberbullying & Primary school (B) & 96 & 389.22 & & & & \\
Behaviour & Secondary school C) & 201 & 379.84 & 4 & 8.08 & .089 & \\
& High school (D) & 221 & 391.09 & & & & \\
Sensitivity & Undergraduate and above (E) & 210 & 342.36 & & & \\
towards & Illiterate (A) & 19 & 289.50 & & & \\
Cyberbullying & Primary school (B) & 96 & 347.58 & & & \\
& Secondary school (C) & 201 & 349.34 & 4 & 15.5 & .004 & E-U \\
& High school (D) & 221 & 373.99 & & & & \\
\hline & Undergraduate and above (E) & 210 & 417.34 & & & \\
\hline
\end{tabular}


The Mann Whitney $U$ test was used to test the significance of the difference between the students' engagement in cyberbullying behaviour and sensitivity towards cyberbullying in terms of having a computer. According to the findings presented in Table 7, while there was no significant difference between the computer ownership variable and the mean scores of engaging in cyberbullying behaviour $\left(U_{l}=67918.00, p>.05\right)$, a significant difference between the students' sensitivity towards cyberbullying $\left(U_{2}=54482.50, p<.05\right)$ was observed. In other words, it has been found that students who own a computer are more sensitive in the context of engaging in cyberbullying behaviour.

Table 7. U-test result regarding the level of engagement in cyberbullying behaviour and cyberbullying sensitivity in terms of the computer ownership variable

\begin{tabular}{|c|c|c|c|c|c|c|}
\hline Variable & $\begin{array}{l}\text { Computer } \\
\text { owner }\end{array}$ & $n$ & $\begin{array}{l}\text { Mean } \\
\text { Ranks }\end{array}$ & $\begin{array}{l}\text { Sum of } \\
\text { Ranks }\end{array}$ & $\boldsymbol{U}$ & $p$ \\
\hline Engaging & Yes & 366 & 369.07 & 135079.00 & & \\
\hline $\begin{array}{l}\text { Cyberbullying } \\
\text { Behaviour }\end{array}$ & No & 381 & 378.74 & 144299.00 & 67918.00 & .489 \\
\hline $\begin{array}{ll}\text { Sennsitivity } & \text { towards } \\
\text { Cyberbullying } & \end{array}$ & $\begin{array}{l}\text { Yes } \\
\text { No }\end{array}$ & $\begin{array}{l}366 \\
381\end{array}$ & $\begin{array}{l}415.64 \\
334.00\end{array}$ & $\begin{array}{l}152124.50 \\
127253.50\end{array}$ & 54482.50 & .000 \\
\hline
\end{tabular}

The Mann Whitney $U$ test was used to test the significance of the difference between the students' engagement in cyberbullying behaviour and their sensitivity towards cyberbullying in terms of having a tablet. While the findings obtained showed that there was no significant difference between the mean scores of having a tablet and cyberbullying engagement $\left(U_{l}=65750.00, p>.05\right)$, their sensibility towards cyberbullying revealed a significant difference between the scores and the tablet ownership variable $\left(U_{2}=60957.50, p<.05\right)$.

Table 8. U-test result regarding the levels of engagement in cyberbullying behaviour and cyberbullying sensitivity in terms of the tablet ownership variable

\begin{tabular}{|c|c|c|c|c|c|c|}
\hline Variable & $\begin{array}{l}\text { Tablet } \\
\text { owner }\end{array}$ & $n$ & $\begin{array}{l}\text { Mean } \\
\text { Rank }\end{array}$ & $\begin{array}{l}\text { Sum of } \\
\text { Ranks }\end{array}$ & $\boldsymbol{U}$ & $p$ \\
\hline Engaging & Yes & 407 & 382.45 & 155658.00 & \multirow[b]{2}{*}{65750.00} & \multirow[b]{2}{*}{.195} \\
\hline $\begin{array}{l}\text { Cyberbullying } \\
\text { Behaviour }\end{array}$ & No & 340 & 363.88 & 123720.00 & & \\
\hline $\begin{array}{l}\text { Sensitivity towards } \\
\text { Cyberbullying }\end{array}$ & $\begin{array}{l}\text { Yes } \\
\text { No }\end{array}$ & $\begin{array}{l}407 \\
340\end{array}$ & $\begin{array}{l}394.23 \\
349.79\end{array}$ & $\begin{array}{l}160450.50 \\
118927.50\end{array}$ & 60957.50 & .005 \\
\hline
\end{tabular}

The Mann Whitney U test was used to test the significance of the difference between the students' engagement in cyberbullying behaviour and their sensitivity towards cyberbullying in terms of having a mobile phone. While the findings showed that there was a significant difference between the phone ownership variable and the cyberbullying engagement mean scores $\left(U_{l}=61251.50, p<.05\right)$, sensitivity towards cyberbullying revealed no significant difference between the mean scores and the mobile phone ownership variable $\left(U_{2}=67240.00\right.$, $p>.05)$. 
Table 9. U-test result regarding engagement in cyberbullying behaviour and cyberbullying sensitivity levels according to the mobile phone ownership variable

\begin{tabular}{|c|c|c|c|c|c|c|}
\hline Variable & $\begin{array}{l}\text { Mobile } \\
\text { Phone } \\
\text { owner }\end{array}$ & $n$ & $\begin{array}{l}\text { Mean } \\
\text { Rank }\end{array}$ & $\begin{array}{l}\text { Sum } \\
\text { Ranks }\end{array}$ & $\boldsymbol{U}$ & $p$ \\
\hline Engaging in & Yes & 418 & 391.97 & 163841.50 & \multirow[b]{2}{*}{61251.50} & \multirow[b]{2}{*}{.005} \\
\hline $\begin{array}{l}\text { Cyberbullying } \\
\text { Behaviour }\end{array}$ & No & 329 & 351.17 & 115536.50 & & \\
\hline $\begin{array}{l}\text { Sensitivity towards } \\
\text { Cyberbullving }\end{array}$ & Yes & $\begin{array}{l}418 \\
329\end{array}$ & $\begin{array}{l}377.64 \\
369.38\end{array}$ & $\begin{array}{l}157853.00 \\
12152500\end{array}$ & 67240.00 & .603 \\
\hline
\end{tabular}

Correlation coefficients regarding engagement in cyberbullying behaviour and sensitivity towards cyberbullying variables are shown in Table 10 . When Table 10 is examined, it can be seen that there is a moderate, negative and significant relationship between the engagement in cyberbullying behaviour and sensitivity towards cyberbullying variables $(r=-.346, p<.01)$. According to this finding, it can be said that as the sensitivity towards cyberbullying increases, the cyberbullying engagement decreases.

Table 10. Relationship between engagement in cyberbullying and sensitivity towards cyberbullying in the educational context

\begin{tabular}{ll}
\hline & Sensitivity towards Cyberbullying \\
\hline Engagement in Cyberbullying & $-.346^{* *}$ \\
\hline$* *$ Correlation is significant difference at level .01. &
\end{tabular}

\section{Discussion, Conclusion and Suggestions}

Cyberbullying behaviour, which is a big problem among the society which can easily affect the young generation in many respects, may cause serious problems among users who have applications used with information technologies such as frustration, sadness, anger (Kestel \& Akbiyık, 2016; Rao et al., 2017; Yaman \& Peker, 2012), fear and tension (Alotaibi, 2019), emotional, behavioural and academic problems (Aizenkot \& Kashy-Rosenbaum, 2019), having negative relationships with family and friends (Kestel \& Akbı11k, 2016), not being able to communicate socially (Ciftci, 2018), feeling of revenge (Yaman \& Peker, 2012) and feeling humiliated, isolated and anxious (Simangunsong, 2020), low self-esteem, emotional and psychological problems, academic difficulties, clinical depression and even suicide (Hinduja \& Patchin, 2010). Thereupon, high sensitivity of users towards cyberbullying behaviour is very important in order not to be affected by it. In this context with this study, it is aimed to determine the level of cyberbullying behaviour engagement and sensitivity towards cyberbullying of secondary school students, who we can refer to as the adolescent generation of the young generation. As a result of the findings obtained in the study, it was seen that students' sensitivity levels regarding cyberbullying were "high", while the levels of students' engagement in cyberbullying behaviour were "low". Similarly, Toraman and Usta (2018) found in their study with secondary school students that students' levels of engagement in cyberbullying behaviour were not very high. Many studies in the literature state that students are exposed to cyberbullying more rather than engaging in cyberbullying behaviour (MacDonald \& Roberts Pittman, 2010), and Similarly, Mishna et al. (2010) stated that exposure to cyberbullying was much more than engaging in cyberbullying behaviour, and that nearly half $(49.5 \%)$ of the sample consisting of 2186 participants were bullied online, $33.7 \%$ of them bullied others online. On the other hand, Yaman and Peker (2012), in their qualitative study with secondary school students, determined that students engage in cyberbullying in the dimensions of cyber linguistic 
bullying, identity hiding and cyber forgery and cyberbullying behaviour due to friendship, boredom, and desire to take revenge. However, the high sensitivity of students towards cyberbullying behaviour is very important so as not to be exposed to such behaviour. Because individuals with high sensitivity also have high awareness and there is an effort to voluntarily being careful about possible threatening situations and their environment (Tanrikulu, Kınay, \& Aricak, 2013). Hence, in this study, it can be said that secondary school students are also competent enough to be sensitive to any cyber aggression against themselves and the people around them.

When the difference in students' engagement in cyberbullying behaviour in terms of gender is examined in the study, it is revealed that males have a higher level of engagement in cyberbullying behaviour than females. Gender differences in cyberbullying studies were extensively studied in the literature, but the findings were found to be inconsistent (Aizenkot \& Kashy-Rosenbaum, 2019). For instance, while it is revealed that males engage in cyberbullying behaviour more than females (Arıcak \& Özbay, 2016; Balaban Salı et al., 2015; Chan \& Wong, 2019; Huang \& Chou, 2010; Kavuk \& Keser, 2016; Li, 2006; Peker , Eroğlu, \& Ada, 2012; Toraman \& Usta, 2018; Wang, Iannotti, \& Nansel, 2009; Yaman, Karakülah, \& Dilmaç, 2013), according to some studies, females engage in cyberbullying behaviour more than males (Eroğlu et al., 2015; Kowalski \& Limber, 2007; Wolak et al., 2007) or studies stating that the gender variable does not have any effect on engaging in cyberbullying behaviour (Balakrishnan, 2015; Didden et al., 2009; Hinduja \& Patchin, 2008; Mesch, 2009) can be found in the literature. In this regard, $\mathrm{Li}$ (2006) concluded that male students are more likely to engage in both traditional and cyberbullying behaviour than female students. As levels of males' cyberbullying behaviour are higher than females in this study and in most of the studies, Eroğlu et al. (2015) and Yaman et al. (2013) emphasized that the relationship between gender and attitude towards violence should be examined and this may be due to the fact that the society supervises females more than males in the internet usage. Eroğlu et al (2015), shared that this difference might be due to the growing influence of different socialization processes of females and males in Turkey. As can be seen from the comments, it can be shown that this difference occurs on the basis of gender in the study, as a result of the fact that males are more freed by the society viz. their behaviour is not supervised or restricted too much, on the other hand, females are more supervised by their families and their behaviour is kept under higher control.

On the other hand, when the difference of students' sensitivity levels towards cyberbullying in terms of gender is examined, it is determined that females have higher sensitivity than males. Although the sensitivity levels of females towards cyberbullying are high, it can be found in many studies that females are exposed to cyberbullying behaviour/being victimized (Peker, 2015; Smith et al., 2006; Wang et al., 2009), and research emphasizing that males are more exposed/ victimized than females (Çiftçi, 2018; Duman \& Bridge, 2019; Kavuk \& Keser, 2016; Peker, 2015) or studies emphasizing that there is no difference between them can be found as well (Arıcak \& Özbay, 2016; Li, 2006; Pekșen Süslü \& Oktay, 2018; Slonje \& Smith, 2008; Ybarra \& Mitchell, 2004). Besides highlighting that there is no difference between females and males in terms of being a victim of cyberbullying, $\mathrm{Li}$ (2006) articulated that female cyberbully victims are more likely to inform adults about it than male cyberbully victims. In a similar fashion, Eden, Heiman and Olenik-Shemesh (2013) stated that female teachers are much more concerned about cyberbullying and believe that it is necessary and important to be informed about dealing with cyberbullying. In this study, it was revealed that female students have higher sensitivity to cyberbullying compared to male students. On the other hand, it is known that females are kept more under control by their families than men and they are constantly warned by their families about paying full attention to what is happening around them (Pekşen Süslü 
\& Oktay, 2018). Therefore, it can be thought that the reason for this finding may have been due to the constant warnings of families about issues such as being careful, cautious and controlled, avoiding and being conscious about any negative behaviors they may encounter even in the virtual environment. On the other hand, owing to the fact that there are very different findings in the literature on both engaging in cyberbullying behaviour and cyberbullying exposure/victimization in terms of gender variable; it is thought that the sample group may be affected by some other parameters e.g. personal development, psychological structure and environmental factor, and this can be seen as a proof of the necessity of many other studies that address these variables and their effects.

Regarding the difference in the levels of students' engagement in cyberbullying behaviour and sensitivity towards cyberbullying in terms of grade level variable, it is determined that $1^{\text {st }}$ year students are more likely to engage in cyberbully behaviour than $2^{\text {nd }}$ year students, while $2^{\text {nd }}$ year students were found to have higher sensitivity towards cyberbullying compared to $1^{\text {st }}$ year students in terms of sensitivity. Similarly, while Toraman and Usta (2018) stated that there was a significant difference at the grade level in their studies and that $2^{\text {nd }}$ and $3^{\text {rd }}$ year students had higher levels of engagement in cyberbullying than $4^{\text {th }}$ year students, Yiğit and Seferoğlu (2019) also reported in their study that the level of cyber security, that is, their awareness increase as the grade level increases. Contrary to the study, Balaban Salı and others (2015) concluded that as the grade level increases, being a victim of cyberbullying behaviour and participation as a bully also increase, whereas Erdur-Baker and Kavşut (2007) indicated that the grade level variables are not associated with being a cyberbully or a cyber victim. On the other hand, it was found that the lower classes had higher cyber bullying, while the upper classes showed higher sensitivity. Thus, in order for students to become conscious about a subject, they are expected to have taken lessons from certain behaviour and to have passed certain stages. In the study, it can be stated with the view that the students in the lower grades tend to engage in cyberbullying behaviour because they are younger and they can be more careful and sensitive as a result of being older or gaining experience when they pass to an upper grade.

In this study, when the difference in the levels of students' engagement in cyberbullying behaviour and sensitivity towards cyberbullying is examined in terms of mother education level and father education level variables, it is seen that there is no significant difference between mother education level and father education level variables and students' engagement in cyberbullying behaviour. On the other hand, in terms of the sensitivity towards cyberbullying, it is seen that the students whose mother education level is undergraduate and graduate have a higher sensitivity than those whose mothers are illiterate, similarly, students whose father education level is undergraduate and graduate have higher sensitivity than students whose father education level is secondary school. In the literature, Akbaba and Eroğlu (2013) emphasized in their study they conducted with elementary school students that the low level of mother and father education increased the level of students' cyberbullying behaviour, similarly, Eroğlu et al. (2015) emphasized that students with a low level of mother education have higher rates of cyberbullying behaviour. However, Laftman et al. (2013) expressed that students with at least one parent who had a university education were less likely victims or perpetrators in cyberbullying behaviour than students whose parents did not have university education. Contrary to the aforementioned studies, as a different finding by Çiftçi (2018), the more advanced the level of education of parents is, the higher the level of cyberbullying and victimization of students is, while Toraman and Usta (2018) emphasized that students' levels of being a cyberbully did not change according to mother or father educational status. In this study, the finding that students whose parents have higher educational status have high sensitivity towards cyberbullying can be explained by the fact that their families are also aware 
of the negative aspects of technology and that they can contribute to the increase in their sensitivity towards cyberbullying by informing their children about this issue.

The significant difference between the variables of having a computer, having a tablet and having a smart phone and cyber bullying were investigated. While there was no significant difference in terms of having a computer and having a tablet, it was revealed that students with a smartphone had a higher rate of cyberbullying. While there is no significant difference between students' sensitivities regarding cyberbullying in terms of having a smartphone, there is a significant difference in favor of those who have a computer and having a tablet. This finding can be explained by the fact that students can avoid cyberbullying behaviour when using computers and tablets in their home environment acting against the risk of being controlled by their families and that they may be more sensitive to such behaviour in line with the possibility of being warned by their families again in the home environment. On the other hand, it can be explained by the comments that students with smart phones can perform these cyber bullying behaviour alone or together with their friends without any control mechanism because they can use these technologies extensively outside the home environment. Similarly, in the literature, though some studies highlight the finding that there is a significant difference between the state of having information technologies and engagement in cyberbullying behaviour (Balaban Sal1 et al., 2015; Toraman \& Usta, 2018), on the contrary, Pekşen Süslü and Oktay (2018), stated that there was no significant difference between cyberbullying and cyber victimization scores depending on the students' having a computer, a mobile phone and a tablet in their study with high school students.

In the study, it can also be seen that there is a moderate, negative and significant relationship between students' engagement in cyberbullying behaviour and their sensitivity towards cyberbullying. As a result of this finding, students are aware of the disadvantages and threats of such negative behaviour, try to stay away from them, try to be careful about these behaviour, be aware of the problems and dangers that may arise for them, in short, they are sensitive towards cyberbullying behaviour, they can also ensure that they do not have such behaviour and avoid situations including such behaviour. In addition to the fact that there is not much research on engaging cyberbullying behaviour and sensitivity towards cyberbullying behaviour in the literature, many studies focus on the relationship between cyberbullying behaviour and being a cyberbullying victim (Balaban Sal1 et al., 2015; Ciftci, 2018; Peker et al., 2012). However, it is also very important to investigate the cases in which students engage in this behaviour and to check their sensitivity towards this behaviour, and to raise awareness of this purpose. On the other hand, ensuring students' sensitivity towards cyberbullying and informing them about it, can help them to stay away from such behaviour by ensuring that they are conscious about both cyberbullying behaviour and exposure to cyberbullying. To cite an example, as Kestel and Akbiyık (2016) counted among the reasons why students engage in or be exposed to such behaviour, it can be explained that they do not have enough information about cyberbullying or dealing with cyberbullying, and parents do not control students enough while they are using information and communication technologies.

Many suggestions can be made for students not to engage in or be exposed to such behaviour. In light of the findings, since male students display more cyberbullying behavior compared to girls, and because of their lower level of sensitivity to cyberbullying, it is recommended that especially male students should be made aware of possible serious problems of cyberbullying behavior by both their families and teachers both for themselves and their environment. On the other hand, since it is seen that lower grade students have more cyber bullying behavior and less sensitivity than upper grade students in the study, various activities can be organized by 
school counselors during the education term for the lower grade students, and what the seriousness and consequences of the situation can cost can be explained to the students with relevant examples of the events. In the study, it can also be suggested that families should be more controlling about the use of smart phones with regard to the finding that there is a relationship between the use of smart phones and cyberbullying behavior. Nevertheless, since the level of education of the mother and father has an effect on being more conscious, that is to say, being more sensitive about this behavior, trainings and seminars delivered by a specialist trainer are also recommended to family members for spotting possible negative effects of this behavior on children, about how to be sensitive towards this behavior and what to pay attention to.

On the other hand, this study has some limitations. The most important limitation of the study is that it included only the students at the secondary school level in a single city centre, and the findings obtained reflect only the personal views of this sample. With a view to generalizing the study, collecting data from different provinces, city centres, districts, towns and villages and incorporating qualitative research methods in the new research may add a new dimension to the studies to be carried out.

\section{References}

Aizenkot, D., \& Kashy-Rosenbaum, G. (2019). Cyberbullying victimization in WhatsApp classmate groups among Israeli elementary, middle, and high school students. Journal of Interpersonal Violence, 1-22. doi:10.1177/0886260519842860

Akbaba, S., \& Eroğlu, Y. (2013). İlköğretim öğrencilerinde siber zorbalık ve mağduriyetin yordayıc1lar1 [The predictors of cyberbullying and cybervictimization in elemantary school students]. Journal of Uludag University Faculty of Education, 26(1), 105-121.

Alotaibi, N. B. (2019). Cyber bullying and the expected consequences on the students' academic achievement. IEEE Access, 7, 153417-153431.

Altundağ, Y., \& Ayas, T. (2020). Lise rehber öğretmenlerine yönelik tüm okul yaklaşımına dayalı sanal zorbalıkla başa çıkma stratejileri ve sanal zorba farkındalığını kazandırma [Effectiveness of the whole school-based program for equipping high school counselors with strategies of coping with cyberbullying and cyberbullying awareness]. Education and Science, 45(201), 109-123 doi:10.15390/EB.2020.8350

Antoniadou, N., \& Kokkinos, C. M. (2018). Empathy in traditional and cyber bullying/victimization involvement from early to middle adolescence: A cross sectional study. Journal of Educational and Developmental Psychology, 8(1), 153-161. ISSN $1927-0526$

Arıcak, O. T. (2011). Siber zorbalık: Gençlerimizi bekleyen yeni tehlike [Cyberbullying: The new danger waiting for adolescent]. Career Window, 2(6), 10-12.

Arıcak, O. T., Kınay, H. ve Tanrıkulu, T. (2012). Siber Zorbalık Ölçeğinin ilk psikometrik bulgular1. HAYEF: Journal of Education, 17(1), 101-114.

Arıcak, O. T., \& Özbay, A. (2016). Investigation of the relationship between cyberbullying, cybervictimization, alexithymia and anger expression styles among adolescents. Computers in Human Behavior, 55, 278-285.

Balaban Salı, J., Ergün Başak, B., \& Baştürk Akça, E. (2015). Türkiye'de ortaokul öğrencileri arasında siber zorbalık [Cyberbullying among Middle School Students in Turkey]. Anadolu Journal of Educational Sciences International, 5(2), 109-130.

Balakrishnan, V. (2015). Cyberbullying among young adults in Malaysia: The roles of gender, age and Internet frequency. Computers in Human Behavior, 46, 149-157. 
Baştürk Akça, E., Sayımer, İ., \& Ergül, S. (2015). Ortaokul öğrencilerinin sosyal medya kullanımları ve siber zorbalık deneyimleri: Ankara örneği [Middle school students' social media use and their cyberbullying experience: A case study from Ankara]. Global Media Journal TR Edition, 5(10), 71-86.

Batmaz, M., \& Ayas, T. (2013). İlköğretim ikinci kademeki öğrencilerin psikolojik belirtilere göre sanal zorbalık düzeylerinin yordanması [Predicting the cyber bullying levels of students in second stage of primary school according to psychological symptoms]. Sakarya University Journal of Education, 3(1), 43-53.

Bauman, S., \& Baldasare, A. (2015). Cyber aggression among college students: Demographic differences, predictors of distress, and the role of the university. Journal of College Student Development, 56(4), 317-330. doi:10.1353/csd.2015.0039

Beale, A. V., \& Hall, K. R. (2020). Cyberbullying: What school administrators (and parents) can do? The Clearing House, 81(1), 8-12.

Belsey, (2015). Bullying, cyberbullying, education, presentations, technology. Retrieved om 3 March 2020 from http://www.billbelsey.com/wp-content/uploads/2015/07/Presentation Descriptions.pdf.

Bingöl, N., \& Tanrıkulu, T. (2014). Siber zorba ve mağdur olma ile algılanan sosyal destek düzeyi arasındaki ilişkinin incelenmesi [The analysis of the relationship between being cyberbullying and cyber victim with the level of the perceived social support]. Akademik Bakış Dergisi, 43, ISSN:1694-528X.

Chan, H.C.O., \& Wong, D.S.W. (2019). Traditional school bullying and cyberbullying perpetration: Examining the psychosocial characteristics of Hong Kong male and female adolescents. Youth \& Society, 51(1), 3-29.

Chibbaro, J. S. (2007). School counsellors and the cyberbully: Interventions and implications. Professional School Counseling, 11(1), 65-68.

Cross, D., Shaw, T., Hadwen, K., Cardoso, P., Slee, P., Roberts, C., Thomas, L., \& Barnes, A. (2016). Longitudinal impact of the cyber friendly schools program on adolescents' cyberbullying behavior. Aggress Behavior, 42,166-180.

Çiftçi, H. (2018). Öğrencilerin siber mağduriyet düzeylerinin karşılaştırılması [Comparison of students' cyber victimization rates]. Gumushane University e-Journal of Facuty of Communication, 6(2), 1536-1567.

Didden, R., Scholte, R. H. J., Korzilius, H., Moor, J. M. H., Vermeulen, A., O'Reilly, M., Lang, R., \& Lancioni, G. E. (2009). Cyberbullying among students with intellectual and developmental disability in special education settings. Developmental Neurorehabilitation, 12(3), 146-151. doi: 10.1080/17518420902971356.

Dilmaç, B., \& Özkan, C. (2019). Lise öğrencilerinde öznel mutluluk, suçluluk ve utancın yordayıcısı olarak siber zorbalık [Cyber bullying as a predictor of subjective happiness, guilt and shame in high school students]. The Journal of Turkish Educational Sciences, 17(1), 195-212.

Dinakar, K., Reichart, R., \& Lieberman, H. (2011). Modeling the detection of textual cyberbullying. Proc. IEEE International Fifth International AAAI Conference on Weblogs and Social Media (SWM'11), Barcelona, Spain.

Duman,. N., \& Bridge, E. N. (2019). Siber mağduriyet [Cyber victimization]. Internetional Journal of Society Researches, 10(17), 1156-1178.

Eden, S., Heiman, T., \& Olenik-Shemesh, D. (2013). Teachers' perceptions, beliefs and concerns about cyberbullying. British Journal of Educational Technology, 44, 10361052.

Erdur-Baker, O., \& Kavşut, F. (2007). Akran zorbalığının yeni yüzü: siber zorbalık [Cyber bullying: A new face of peer bullying]. Eurasian Journal of Educational Research, 27, $31-42$. 
Erişti, B., \& Akbulut, Y. (2017). Reactions to cyberbullying among high school and university students. The Social Science Journal, 56(1), 10-20. doi: 10.1016/j.soscij.2018.06.002

Eroğlu, Y., \& Güler, N. (2015). Koşullu öz-değer, riskli internet davranışları ve siber zorbalık/mağduriyet arasındaki ilişkinin incelenmesi [The investigation relationships among contingencies of self-worth, risky internet behaviors and cyberbullying/cybervictimization]. Sakarya University Journal of Education, 5(3), 118129. doi: $10.19126 /$ suje.56594

Eroğlu, Y., Aktepe, E., Akbaba, S., Işık, A., \& Özkorumak, E. (2015). Siber zorbalık ve mağduriyetin yaygınlığının ve risk faktörlerinin incelenmesi [The investigation of prevalence and risk factors associated with cyber bullying and victimization]. Education and Science, 40(177), 93-107.

Gezgin, D. M., \& Çuhadar, C. (2012). Bilgisayar Öğretim Teknolojileri Eğitimi Bölümü öğrencilerinin siber zorbalığa ilişkin duyarlılık düzeylerinin incelenmesi [Investigation of the Computer Education and Instructional Technologies students' awareness to cyber-bullying]. Journal of Educational Sciences Research, 2(2), 93-100.

Hinduja, S., \& Patchin, J. W. (2008) Cyberbullying: An exploratory analysis of factors related to offending and victimization. Deviant Behaviour, 29(2), 129-156. doi: $10.1080 / 01639620701457816$

Hinduja, S., \& Patchin, J. W. (2010). Bullying, cyberbullying, and suicide. Archives of Suicide Research, 14(3), 206-221. doi: 10.1080/13811118.2010.494133

Horzum, M. B., \& Ayas, T. (2014). Orta öğretim öğrencilerin psikolojik belirtilere göre sanal zorba ve sanal mağdur düzeylerinin yordanması [Predicting cyberbully and cybervictim levels of secondary education students according to psychological symptoms]. Online Journal of Technology Addiction \& Cyberbullying, 1(2), 21-36.

Huang, Y., \& Chou, C. (2010). An analysis of multiple factors of cyberbullying among junior high school students in Taiwan. Computers in Human Behavior, 26, 1581-1590.

Jimenez, R. (2019). Multiple victimization (Bullying and Cyberbullying) in primary education in Spain from a gender perspective. Multidisciplinary Journal of Educational Research, 9(2), 169-192. doi: 10.4471/remie.2019.4272

Karasar, N. (2005). Scientific Research Method, (15 th Ed.). Ankara: Nobel Yayınevi.

Kasahara, G. M., Houlihan, D., \& Estrada, C. (2019). Gender differences in social media use and cyberbullying in Belize: A preliminary report. International Journal of Psychology Studies, 11(2), 32-41.

Kavuk Kalender, M., Keser, H., \& Tugun, V. (2019). Ortaokul ve lise öğrencilerinin siber zorbalık görüşleri, deneyimleri ve müdahale davranışları [Middle and high school students' opinions, experiences and responses regarding to cyberbullying]. Education and Science, 44(198), 183-200.

Kavuk, M., \& Keser, H. (2016). İlköğretim okullarında siber zorbalık [Cyberbullying at primary school]. Hacettepe University Journal of Education, 31(3), 520-535.

Keser, H. \& Kavuk, M. (2015). Okulda siber zorbalık farkındalık anketinin geliştirilmesi [Developing a questionnaire for cyberbullying awareness at school]. Kastamonu Education Journal, 23, 17-30.

Kestel, M., \& Akbıyık, C. (2016). Siber zorbalığın öğrencilerin akademik, sosyal ve duygusal durumları üzerindeki etkisinin incelenmesi [An investigation of effects of cyber bullying on students' academic, social and emotional states]. Mersin University Journal of the Faculty of Education, 12(3), 844-859. doi: $10.17860 /$ mersinefd.282384.

Kowalski, R.M., \& Limber, S. P. (2007). Electronic bullying among middle school students. The Journal of Adolescent Health: Official publication of the Society for Adolescent. Medicine, 41(6), 22-30. 
Kurniasih, N., Kurwarno, E., Yanto, A., \& Sugiana, D. (2020). Media literacy to overcome cyberbullying: case study in an elementary school in bandung Indonesia. Library Philosophy and Practice (e-journal), 1-8. ISSN 1522-0222.

Laftman, S. B., Modin, B., \& Östberg, V. (2013). Cyberbullying and subjective health: A largescale study of students in Stockholm, Sweeden. Children and Youth Services Review, $35,112-119$.

Li, Q. (2006). Cyberbullying in schools: A research of gender differences. School Psychology International, 27, 157-170. doi:10.1177/ 0143034306064547.

MacDonald, C. D., \& Roberts Pittman, B. (2010). Cyberbullying among college students: prevalence and demographic differences. Procedia Social and Behavioral Sciences, 9, 2003-2009.

Mesch, G. S. (2009). Parental mediation, online activities, and cyberbullying. Cyberpsychology, Behavior, and Social Networking, 12(4), 387-393.

Mishna, F., Cook, C., Gadalla, T., Daciuk, J., \& Solomon, S. (2010). Cyber bullying behaviors among middle and high school students. American Journal of Orthopsychiatry, 80(3), 362-374. doi: 10.1111/j.1939-0025.2010.01040.x

Özgür, H. (2015). Exploring the distance education students' cyberbullying, cybervictimization and cyberbullying sensibility levels. Turkish Online Journal of Distance EducationTOJDE, 16(4), 3-17.

Özdemir, M., \& Akar, F. (2011). Lise öğrencilerinin siber-zorbalığa ilişkin görüşlerinin bazı değişkenler bakımından incelenmesi [Examination of high school students' opinions on cyberbullying in terms of various variables]. Educational Administration: Theory and Practice, 17(4), 605-626.

Patchin, J. W., \& Hinduja, S (2006). Bullies move beyond the schoolyard: a preliminary look at cyberbullying. Youth Violence and Juvenile Justice, 4(2), 148-169.

Patchin, J. W., \& Hinduja, S. (2010). Cyberbullying and self-esteem. Journal of School Health, 80(12), 614-621. doi:10.1111/j.1746-1561.2010 .00548.x

Peker, A. (2015). Ortaokul öğrencilerinin siber zorbalık statülerini yordayan risk faktörlerinin incelenmesi [Analyzing the risk factors predicting the cyberbullying status of secondary school students]. Education and Science, 40(181), 57-75.

Peker, A., Eroğlu Y., \& Ada, Ş. (2012). Ergenlerde siber zorbalığın ve mağduriyetin yordayıcilarının incelenmesi [The investigation of predictors of cyberbullying and cybervictimization in adolescents]. Journal of Abant Izzet Baysal University, 12(2), 185-206.

Pekşen Süslü, D., \& Oktay, A. (2018). Lise öğrencilerinde siber zorbalık ve siber mağduriyetle ilişkili bazı değişkenlerin incelenmesi [Investigating some variables related to cyberbullying and cyber victimization in high school students]. Elementary Education Online, 17(4), 1877-1895.

Rao, J., Wang, H., Pang, M., Yang, J., Zhang, J., Ye, Y., Chen, X., Wang, S., \& Dong, X. (2017). Cyberbullying perpetration and victimization among junior and senior high school students in Guangzhou, China. Injury Prevention, 13-19.

Ronis, S., \& Slaunwhite, A. (2019). Gender and geographic predictors of cyberbullying victimization, perpetration, and coping modalities among youth. Canadian. Journal of School Psychology, 34, 3-21.

Sampasa-Kanyinga, H., Lalande, K., \& Colman, I. (2020). Cyberbullying victimisation and internalising and externalising problems among adolescents: The moderating role of parent-child relationship and child's sex. Epidemiology and Psychiatric Sciences, 29(8), 1-10. doi: 10.1017/S2045796018000653. 
Simangunsong, E. (2020). Cyberbullying: Identification of factors affecting the quality of higher education in Indonesia. Education, Sustainability \& Society (ESS), 3(1), 15-19. doi: 10.26480/ess.01.2020.15.19.

Slonje, R., \& Smith, P. K. (2008). Cyberbullying: Another main type of bullying? Scandinavian Journal of Psychology, 49, 147-154.

Smith, P. K., Mahdavi, J., Carvalho, M., \& Tippett, N. (2006). An investigation into cyberbullying, its forms, awareness and impact, and the relationship between age and gender in cyberbullying. London, England: Department for Education and Skills, Research Brief No. RBX03-06. DfES, London

Smith, P. K., Mahdavi, J., Carvalho, M., Fisher, S., Russell, S., \& Tippett, N. (2008). Cyberbullying: Its nature and impact in secondary school pupils. Journal of Child Psychology and Psychiatry, 49, 376-385

Şahin, M., Sarı, S. V., Özer, Ö., \& Er, S. H. (2010). Lise öğrencilerinin siber zorba davranışlarda bulunma ve maruz kalma durumlarına ilişkin görüşleri [High school students' views about their cyber bully behaviours and self-exposition]. Suleyman Demirel University Faculty of Science and Literature Journal of Social Science, 21, 257-270.

Tanrıkulu, T., Kınay, H., \& Arıcak, O. T. (2013). Siber zorbalığa ilişkin duyarlılık ölçeği: Geçerlik ve güvenirlik çalışması [Cyberbullying sensibility scale: Validity and reliability study]. Trakya University Journal of Education, 3(1), 38-47.

Tanrikulu, İ. (2017). Cyberbullying prevention and intervention programs in schools: A systematic review. School Psychology International, 74-91. doi:10.1177/0143034317745721.

Tanrıkulu, İ. (2019). Okul çağındaki çocuklar siber zorbalık yapmayı nasıl öğreniyorlar? [How do school children learn cyberbullying perpetration?]. Journal of Theoretical Educational Science, 12(1), 16-27. doi:10.30831/akukeg.512556

Tokunaga, R. S. (2010). Following you home from school: A critical review and synthesis of research on cyberbullying victimization. Computers in Human Behavior, 26, 277-287. doi: 10.1016/j.chb.2009.11.014.

Toraman, L., \& Usta, E. (2018). Ortaokul öğrencilerinin dijital yerli ve siber zorba olma durumlarının çeşitli değişkenler açısından incelenmesi [The analysis of the cases of being a digital native and cyber bully of the secondary school students in terms of various variables]. Ondokuz Mayis University Journal of EducationFaculty, 37(2), 5777.

Varela, J. J., Zimmerman, M. A., Ryan, A. M., \& Stoddard, S. A. (2018). Cyberbullying among Chilean students and the protective effects of positive school communities. Journal of School Violence, 17, 430-442. doi:10.1080/15388220.2017.1358640.

Wang, P., Wang, X., \& Lei, L. (2019). Gender differences between student-student relationship and cyberbullying perpetration: An evolutionary perspective. Journal of Interpersonal Violence, 1-21. doi: 10.1177/0886260519865970 .

Wang, J., Iannotti, R. J., \& Nansel, T. R. (2009). School bullying among adolescents in the United States: physical, verbal, relational, and cyber. Journal of Adolescent Health, 45, 368-375. doi: 10.1016/j.jadohealth.2009.03.021

Wolak, J., Mitchell, K. J., \& Finkelhor, D. (2007). Does online harassment constitute bullying? An exploration of online harassment by known peers and online-only contacts. Journal of Adolescent Health, 41, 51-58.

Yaman, E., \& Peker, A. (2012). Ergenlerin siber zorbalık ve mağduriyete ilişkin algıları [The perceptions of adolescents about cyberbullying and cybervictimization]. Gaziantep University Journal of Social Sciences, 11(3), 819-838. 
Yaman, E., Karakülah, D., \& Dilmaç, B. (2013). İlköğretim ikinci kademe öğrencilerinin değerlerini yordayan iki önemli değişken: Siber zorbalık eğilimleri ve okul kültürü arasındaki ilişki [Two important variables that predict values of secondary school students: relationship between cyber-bullying tendencies and school culture]. Journal of Values Education, 11(26), 323-337.

Yiğit, M. F., \& Seferoğlu, S. S. (2019). Öğrencilerin siber güvenlik davranışlarının beş faktör kişilik özellikleri ve çeşitli diğer değişkenlere göre incelenmesi [Investigating students' cyber security behaviors in relation to big five personality traits and other various variables]. Mersin University Journal of the Faculty of Education, 15(1), 186-215. doi: 10.17860/mersinefd.437610

Yiğit, M., Keskin, S., \& Yurdagül, H. (2018). Ortaokullarda siber zorbalık ve aile desteği arasındaki ilişkinin cinsiyet, internet kullanımı ve öğrenim düzeyi bağlamında incelenmesi [Investigating the relationship between cyberbullying and perceived family support in middle-school students in relation to gender, frequency of internet use, and grade]. The Turkish Journal on Addictions, 5(2), 249-284. 